Article

\title{
Interstitial Arabidopsis-Type Telomeric Repeats in Asteraceae
}

\author{
Alexis J. Maravilla ${ }^{1}$ (D), Marcela Rosato ${ }^{1}$, Inés Álvarez ${ }^{2} \mathbb{D}$, Gonzalo Nieto Feliner ${ }^{2}$ (D) and Josep A. Rosselló ${ }^{1, *}$ \\ 1 Jardín Botánico, Instituto Cavanilles de Biodiversidad y Biología Evolutiva, Universitat de València, \\ c/Quart 80, E-46008 Valencia, Spain; maravil3@alumni.uv.es (A.J.M.); marcela.rosato@uv.es (M.R.) \\ 2 Real Jardín Botánico (RJB), Consejo Superior de Investigaciones Científicas (CSIC), Plaza de Murillo 2, \\ E-28014 Madrid, Spain; ines@rjb.csic.es (I.Á.); nieto@rjb.csic.es (G.N.F.) \\ * Correspondence: rossello@uv.es; Tel.: +34-963-156-800
}

Citation: Maravilla, A.J.; Rosato, M.; Álvarez, I.; Nieto Feliner, G.; Rosselló, J.A. Interstitial Arabidopsis-Type Telomeric Repeats in Asteraceae. Plants 2021, 10, 2794. https:// doi.org/10.3390/plants10122794

Academic Editors: Boz̀ena Kolano and Natalia Borowska-Zuchowska

Received: 16 November 2021 Accepted: 13 December 2021 Published: 17 December 2021

Publisher's Note: MDPI stays neutral with regard to jurisdictional claims in published maps and institutional affiliations.

Copyright: (c) 2021 by the authors. Licensee MDPI, Basel, Switzerland. This article is an open access article distributed under the terms and conditions of the Creative Commons Attribution (CC BY) license (https:/ / creativecommons.org/licenses/by/ $4.0 /)$.

\begin{abstract}
Tandem repeats of telomeric-like motifs at intra-chromosomal regions, known as interstitial telomeric repeats (ITR), have drawn attention as potential markers of structural changes, which might convey information about evolutionary relationships if preserved through time. Building on our previous work that reported outstanding ITR polymorphisms in the genus Anacyclus, we undertook a survey across 132 Asteraceae species, focusing on the six most speciose subfamilies and considering all the ITR data published to date. The goal was to assess whether the presence, site number, and chromosomal location of ITRs convey any phylogenetic signal. We conducted fluorescent in situ hybridization (FISH) using an Arabidopsis-type telomeric sequence as a probe on karyotypes obtained from mitotic chromosomes. FISH signals of ITR sites were detected in species of subfamilies Asteroideae, Carduoideae, Cichorioideae, Gymnarhenoideae, and Mutisioideae, but not in Barnadesioideae. Although six small subfamilies have not yet been sampled, altogether, our results suggest that the dynamics of ITR formation in Asteraceae cannot accurately trace the complex karyological evolution that occurred since the early diversification of this family. Thus, ITRs do not convey a reliable signal at deep or shallow phylogenetic levels and cannot help to delimitate taxonomic categories, a conclusion that might also hold for other important families such as Fabaceae.
\end{abstract}

Keywords: interstitial telomeric repeats; Arabidopsis-type ITR; FISH; Asterales; Asteraceae; cytogenetic evolution

\section{Introduction}

Telomeres are the natural ends of eukaryotic linear chromosomes. They are constituted by ribonucleoprotein complexes that differ notably from other DNA sequences in both structure and function. Capping the chromosome ends by telomere structures facilitates the protection of genetic material against double-stranded breaks, degradation, and end-to-end fusion with other chromosomes, which lead to genome instability [1-3].

Telomeric regions are constituted by large stretches of DNA sequences that are GC rich and are usually tandemly arranged to attain up to several thousands of base pairs in length [4]. Overall, telomeric sequences are highly conserved across groups of unrelated organisms although lineage specific motifs are known too $[5,6]$. In land plants, the dominant consensus telomere repeat is composed of seven nucleotides known as the Arabidopsis-type (TTTAGGG) $)_{\mathrm{n}}$ [6-8], but divergent repeat motifs have been recognized [9-17]. It has been recently suggested that beyond the telomere motif exceptions detected, the real diversity in telomeric sequences in land plants has been probably underestimated [18].

Tandem repeats of telomeric-like motifs have been reported also at intrachromosomal regions, known as interstitial telomeric repeats (ITR) or interstitial telomeric sequences [19]. The use of molecular cytogenetic techniques has allowed the detection of ITRs in unrelated organisms [7,8,20-24]. Overall, these studies have interpreted the occurrence of ITRs as stable karyological landmarks that they may be remnants of end-to-end fusion events between non-homologous chromosomes, translocations, inversions, and heterologous 
chromosomal recombination [19,25]. Compared to other popular landmarks used in plant molecular cytogenetics, such as the 35S and 5S rDNA families [26], efforts devoted to assess the presence, phylogenetic distribution, and evolutionary significance of ITRs in land plants have been scanty.

Asteraceae (Compositae), with an estimated 25,000-35,000 species, comprises about $10 \%$ of all flowering plant diversity [27]. This family has been extensively characterized from a basic cytogenetic perspective, based partly on a vast amount of data accumulated on chromosome numbers [28-30]. This has allowed to substantiate a hypothesis concerning chromosomal base number evolution [29] and to understand the patterns of karyological change after multiple polyploidization events that have occurred across Asteraceae in its early evolutionary history [31].

Reports indicating the presence of ITRs in this family are known since the work of [8]. However, the number of taxa analyzed to date remains limited and includes only 53 species (and one subspecies) belonging to 20 genera [8,32-50]. Most of the species analyzed to date are restricted to subfamily Asteroideae (Table S1). ITRs have been detected in 12 species, six of which belong in the genus Anacyclus [49]. The fact that most surveys usually include sparse and limited taxonomic samplings precludes obtaining a broad perspective on the evolutionary significance of the presence, location and amplification of ITR sites in Asteraceae.

In this paper, we assess the presence of ITRs in Asteraceae using a comparatively large sampling scheme compared to previous studies [8,32-50]. We aimed to cover a broad phylogenetic range and analyze the available data from an evolutionary perspective. To this end, we have used an Arabidopsis-type telomeric sequence as a probe to reveal the presence of ITRs in karyotypes obtained from mitotic chromosomes. In situ hybridization techniques have become one of the most powerful approaches for mapping specific sequences of DNA in plant cytogenetics, including telomere sequences [51]. Specifically, fluorescent in situ hybridization (FISH) involves the indirect (through haptens) or direct labelling of a fluorescence probe followed by annealing to the target sequences of individual cells with subsequent visualization by epifluorescence microscopy [52].

The overall objective was to explore whether the presence of ITRs, the site number, and their chromosomal location in Asteraceae convey any phylogenetic signal, i.e., if they were retained over evolutionary time or, alternatively, whether ITRs are labile chromosomal landmarks and thus poor phylogenetic predictors. Specifically, the goals of our study were (a) to investigate whether ITR loci are present within the most speciose subfamilies (Barnadesioideae, Mutisioideae, Carduoideae, Cichorioideae, and Asteroideae) and the monospecific Gymnarhenoideae by analysing the somatic karyotypes of 132 species and two subspecies from 108 genera and reviewing previous available data, (b) to examine the patterns of site number and chromosomal ITR distribution across major evolutionary groups, (c) to examine the association between the patterns of chromosome evolution and eventual cycles of amplification, genomic spread, and contraction of ITRs.

\section{Results}

\subsection{New Observations}

FISH signals of ITR sites were detected in species of Asteroideae (Figure 1), Carduoideae (Figure 2A,B), Cichorioideae (Figure 3), Gymnarhenoideae (Figure 2D), and Mutisioideae (Figure 2C). Interstitial telomeric-like repeats were neither observed in Barnadesioideae accessions nor in the two sampled species of the related families Calyceraceae and Goodeniaceae (Asterales) used for comparative purposes. Overall, ITR signals were observed in 24 species (18.18\% of our samples) belonging to 20 genera $(18.52 \%)$. 


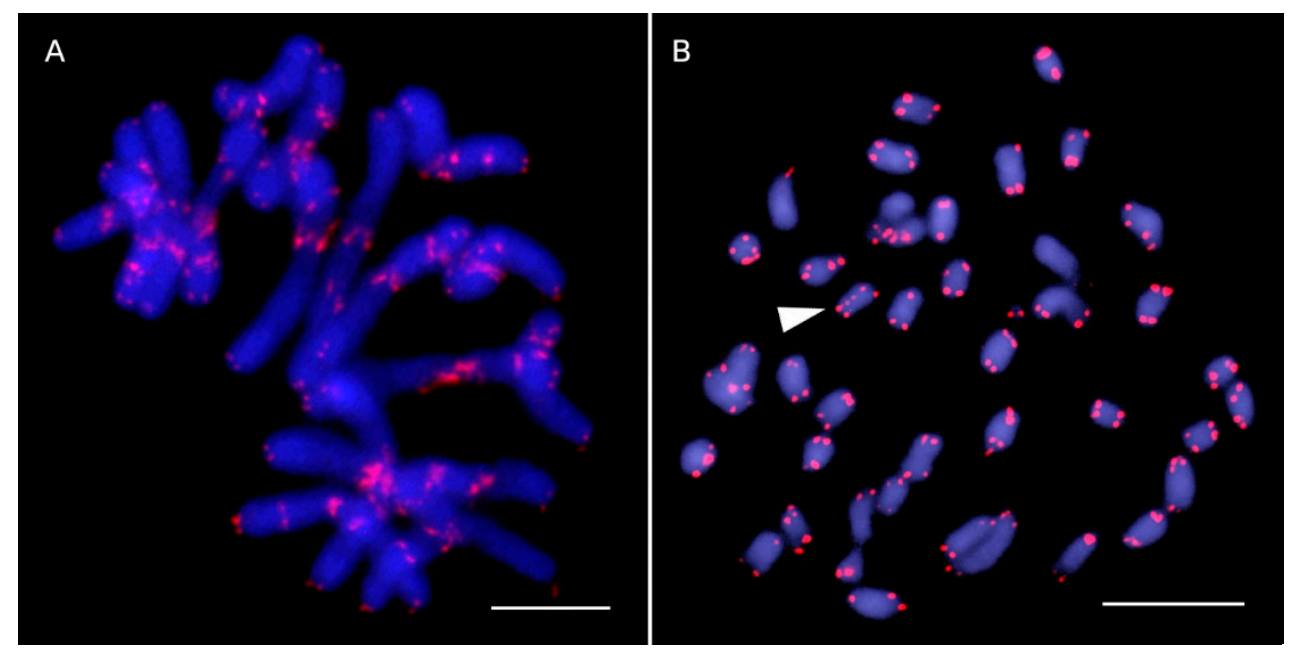

Figure 1. Telomeric-like sequence (TTTAGGG) $\mathrm{n}$ sites in Asteroideae species assessed by FISH analysis. Telomeric sites and interstitial telomeric repeat (ITR) sites are shown as red fluorescent signals and the chromosomes are counterstained with 4, 6-diamidino-2-phenylindole (DAPI) (blue colour). (A) Cota nigellifolia $(2 n=18)$, showing 52 ITR sites. (B) Senecio vulgaris $(2 n=40$,) with two ITR sites (arrowhead) located in the same chromosome. Scale bars: $10 \mu \mathrm{m}$.

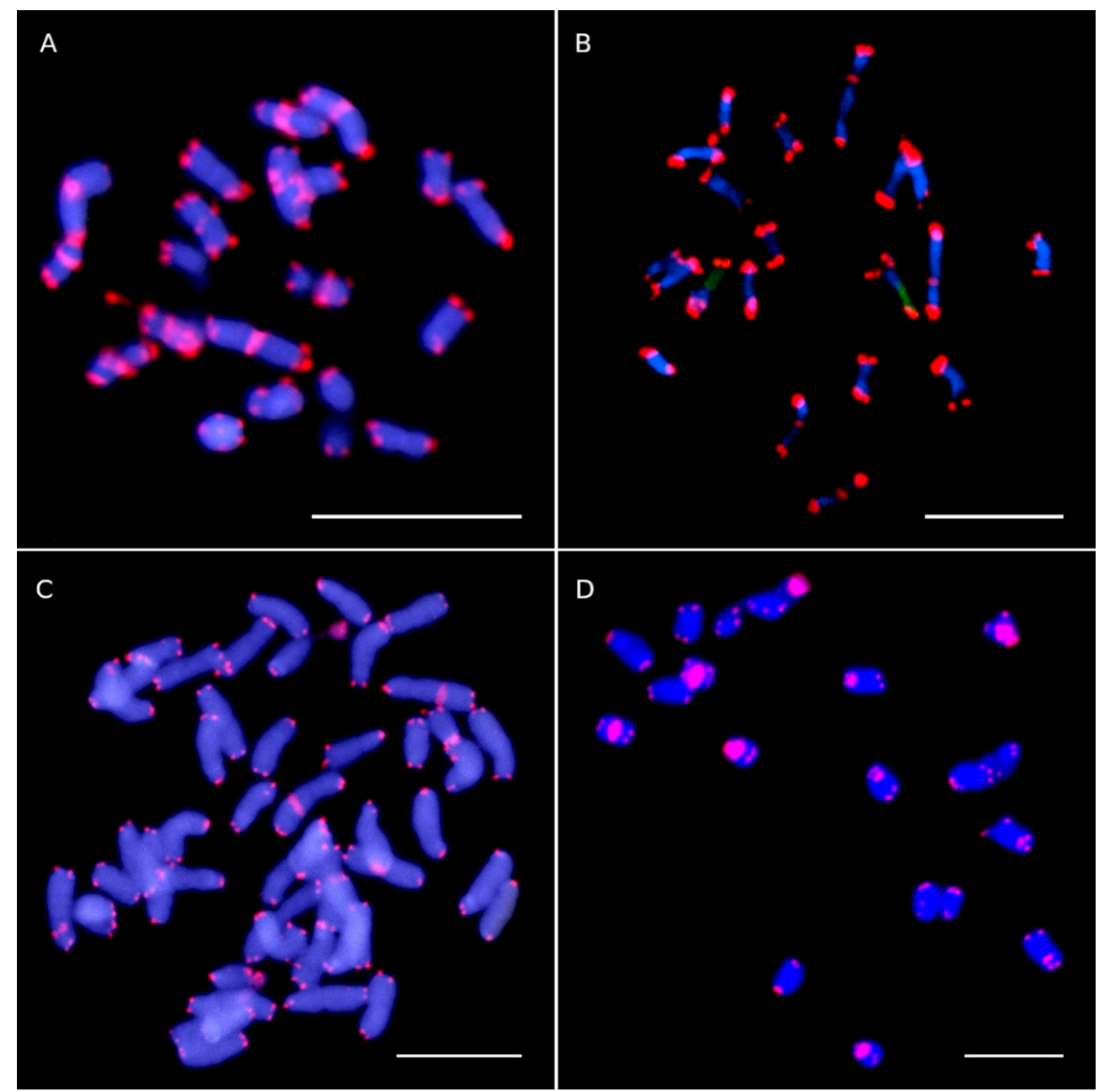

Figure 2. Telomeric-like sequence (TTTAGGG) $n$ sites in representative species of Carduoideae (A,B), Mutisioideae (C) and Gymnarhenoideae (D) tribes assessed by FISH analysis. Telomeric sites and 
interstitial telomeric repeat (ITR) sites are shown as red fluorescent signals and the chromosomes are counterstained with 4, 6-diamidino-2-phenylindole (DAPI) (blue colour). (A) Galactites tomentosa $(2 n=20)$ showing 10 ITR sites. (B) Carlina hispanica $(2 n=18+2 B)$ with six ITR sites. (C) Nassauvia sprengelioides $(2 n=44)$ with four ITR sites). (D) Gymnarrhena micrantha $(2 n=20)$ showing ten ITR sites. Faint ITR signals are marked with arrowheads. Scale bars: $10 \mu \mathrm{m}$.

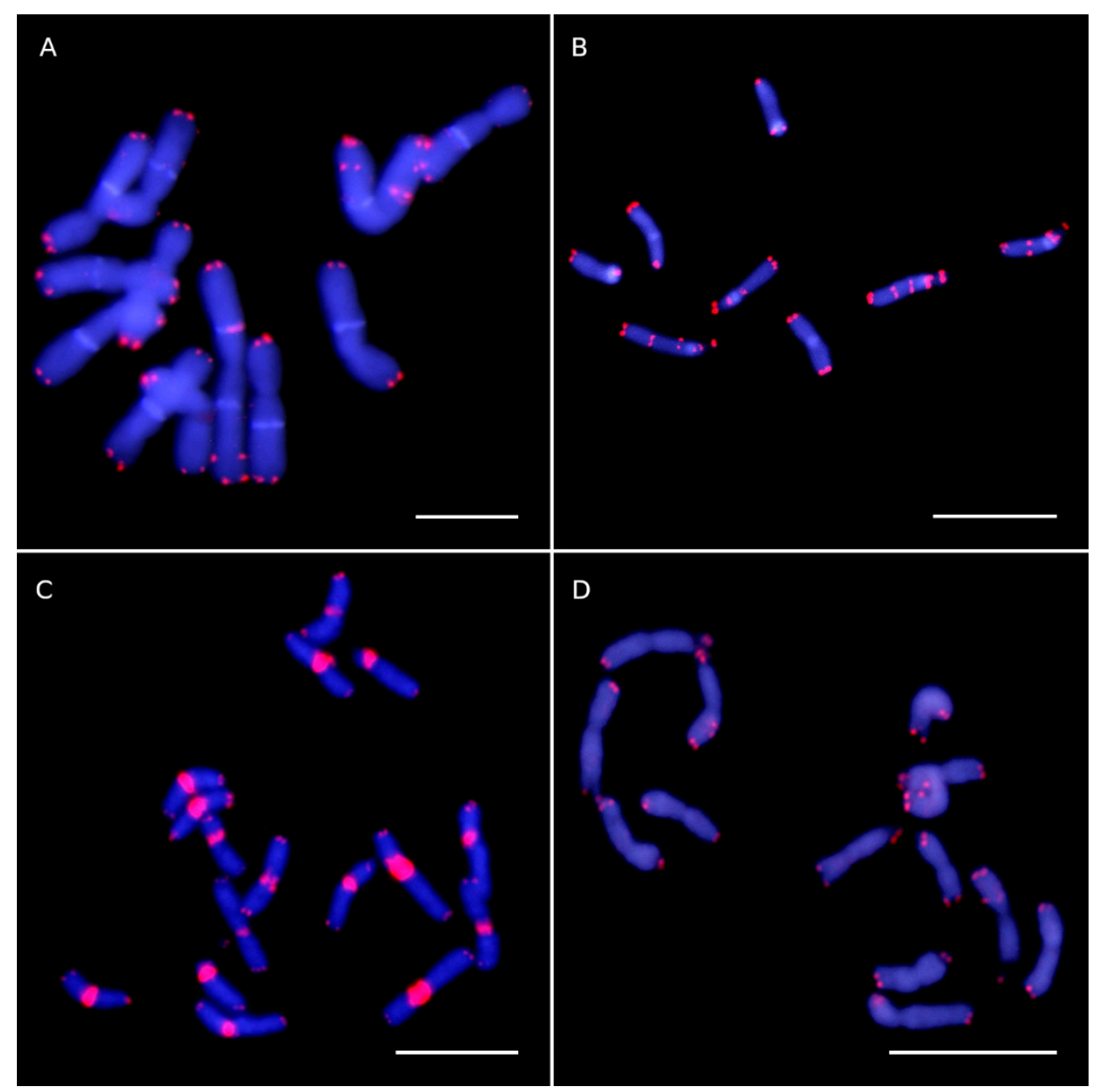

Figure 3. Telomeric-like sequence (TTTAGGG) $)_{n}$ sites in representative species of Cichorioideae (A-D) tribes assessed by FISH analysis. Telomeric sites and interstitial telomeric repeat (ITR) sites are shown as red fluorescent signals and the chromosomes are counterstained with 4, 6-diamidino-2phenylindole (DAPI) (blue colour). (A) Stokesia laevis $(2 n=14)$ with four sites. Two chromosomes were missed from the metaphase plate. (B) Leontodon longirostris $(2 n=8)$ with ten ITR sites. (C) Hyoseris taurina $(2 n=16)$ with 18 ITR sites. (D) Sonchus tenerrimus subsp. tenerrimus $(2 n=14)$ showing two sites. Scale bars: $10 \mu \mathrm{m}$.

In the studied accessions showing ITRs, the number of sites ranged from two (Anthemis cotula, Tanacetum vulgare, Leucanthemum graminifolium, Senecio vulgaris, Dymondia margaretae, Sonchus tenerrimus subsp. tenerrimus, and Leontodon tuberosus) to 52 in Cota nigellifolia, the highest number so far reported in Asteraceae. Intrageneric differences in the presence or absence of ITR signals were observed in Achillea (two absences, one presence), Anthemis (three absences, two presences), Cladanthus (one absence, one presence), Nassauvia (one absence, one presence), and Sonchus (one absence, one presence) accessions. Intraspecific variation was detected in a single species, Sonchus tenerrimus. Two ITR sites were present in subsp. tenerrimus whereas none were found in the closely related subsp. dianae.

ITR sites preferentially occur as homozygous loci (21 species). However, odd numbers of ITR sites reflecting a hemyzygous state were detected in Gonospermum fruticosum 
(29 sites), Achillea ligustica (17 sites), and Anthemis tinctoria (3 sites). The intensity of the ITR signals detected by FISH varied between site locations and samples, suggesting that a variable number of repeats are involved (Figure 4). For instance, faint ITR signals (showing lower intensity than the telomeric sites) were detected in Stokesia laevis (Figure 3A). The opposite was detected in Hyoseris taurina where the centromeric ITR sites showed a remarkably higher intensity than those present at the chromosome ends (Figure 3C).

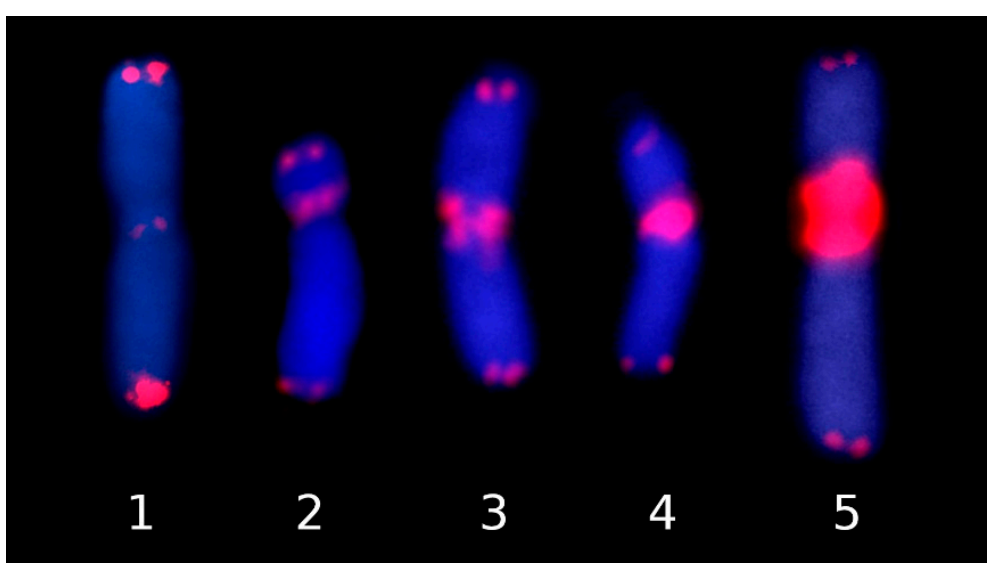

Figure 4. Differences in the signal intensity of ITR sites detected in Asteraceae chromosomes. (1): Anacyclus clavatus; (2): Leontodon tuberosus; (3-5): Hyoseris taurina.

\subsection{Patterns of ITR Variation in Asteraceae}

Our results in addition to previous reports of ITR sites in Asteraceae [8,32-50], including the chromosome number, presence and number of ITR signals, and their chromosomal distribution are indicated in Table S1.

Altogether 176 species and three subspecies included in 115 genera have been analyzed for ITR. Of these, ITR signals have been detected in 36 species (20.11\%) and 25 (21.74\%) genera. The phylogenetic distribution of the species showing ITRs is shown in Figure 5 and Table 1.

Table 1. Taxonomic distribution of ITR sites in Asteraceae and some related families as assessed by FISH. For each major lineage (subfamily), the number of sampled tribes, genera and species is indicated; the number of taxa showing ITR sites in parenthesis. Data are from previous reports [8,32-50] and our own results.

\begin{tabular}{cccccc}
\hline Family & Subfamily & No. of Tribes & $\begin{array}{c}\text { No. of } \\
\text { Genera }\end{array}$ & $\begin{array}{c}\text { No. of } \\
\text { Species }\end{array}$ & $\begin{array}{c}\text { No. of } \\
\text { Subsp. }\end{array}$ \\
\hline Asteraceae & Asteroideae & $11(2)$ & $62(15)$ & $97(24)$ & 1 \\
\hline & Carduoideae & $1(1)$ & $21(2)$ & $31(2)$ & 1 \\
\hline & Cichorioideae & $2(2)$ & $21(6)$ & $35(8)$ & 1 \\
\hline & Gymnarrhenoideae & $1(1)$ & $1(1)$ & $1(1)$ & 0 \\
\hline Calyceraceae & Mutisioideae & $3(1)$ & $8(1)$ & $10(1)$ & 0 \\
\hline Goodeniaceae & Barnadesioideae & $1(0)$ & $2(0)$ & $2(0)$ & 0 \\
\hline Campanulaceae & & & $1(0)$ & $1(0)$ & 0 \\
\hline Stylidaceae & & & $1(0)$ & $2(0)$ & 0 \\
\hline
\end{tabular}




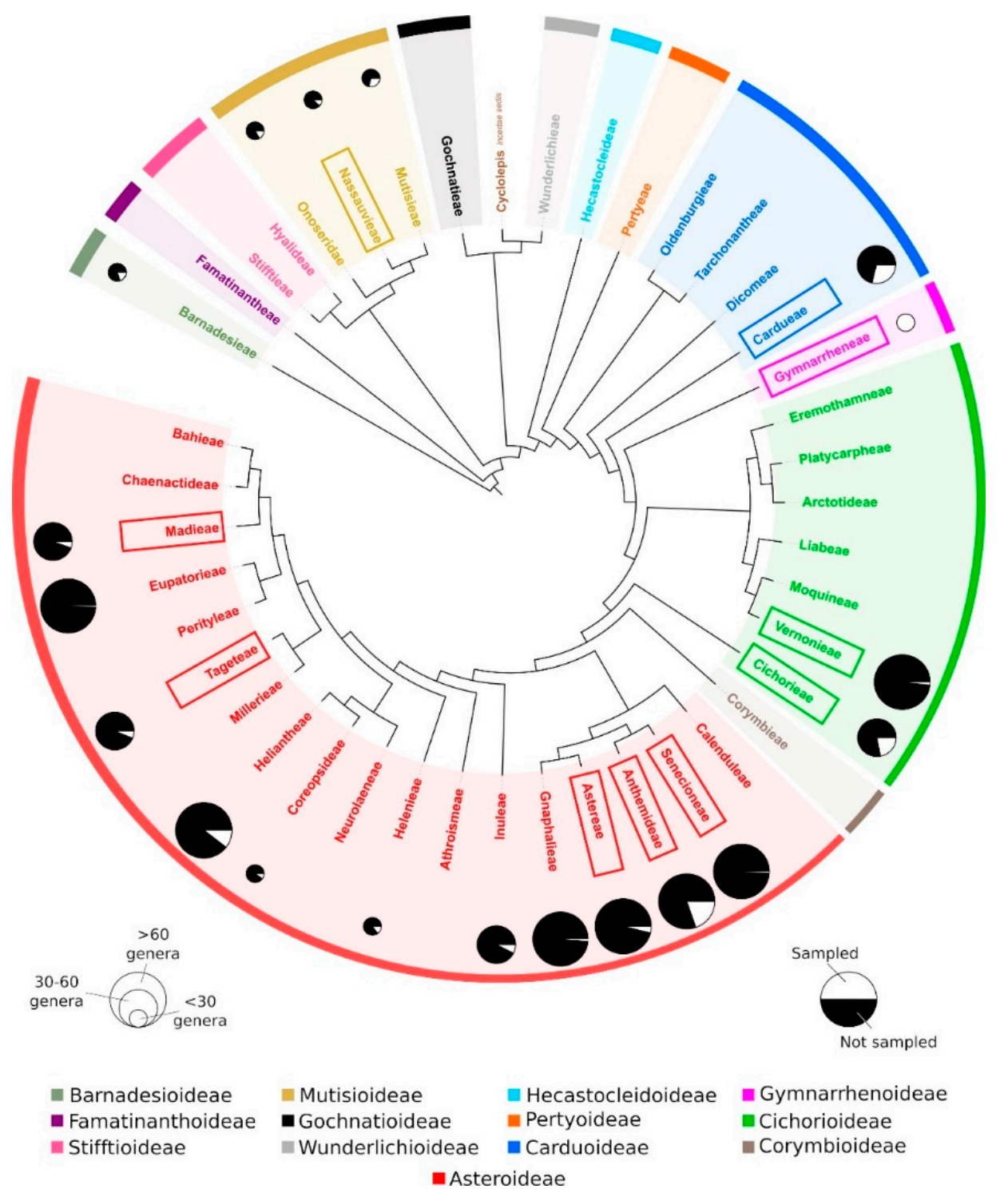

Figure 5. Overview of the phylogenetic relationships among tribes of Asteraceae [27]. The proportion of sampled genera for each analyzed tribe is indicated. Tribes showing ITR sites are boxed.

No association between the presence of ITRs and the evolutionary placement of the species has been evidenced. ITRs have been recorded from 11 tribes, distributed across the phylogenetic tree of the family, including both early-diverging (Nassauvieae) and more recently diverged lineages (Cardueae, Gymnarrheneae, Vernonieae, Cichorieae, Senecioneae, Anthemidae, Astereae, Tageteae, and Madieae).

ITR sites are present across a wide range of chromosome numbers, from species with $2 n=4$ (Xanthisma gracile) to $2 n=68$ (Porophyllum ruderale). No apparent relation was detected between the number of ITR sites and the chromosome number of the species (Pearson correlation value $\mathrm{r}=-0.05, p=0.6213$; Figure 6 ), even if the results are analyzed separately for each subfamily (data not shown). This is clearly observed in Asteroideae, where species showing the same chromosome number $(2 n=18)$ exhibit the widest range of ITR sites (2-52; Figure 6). 

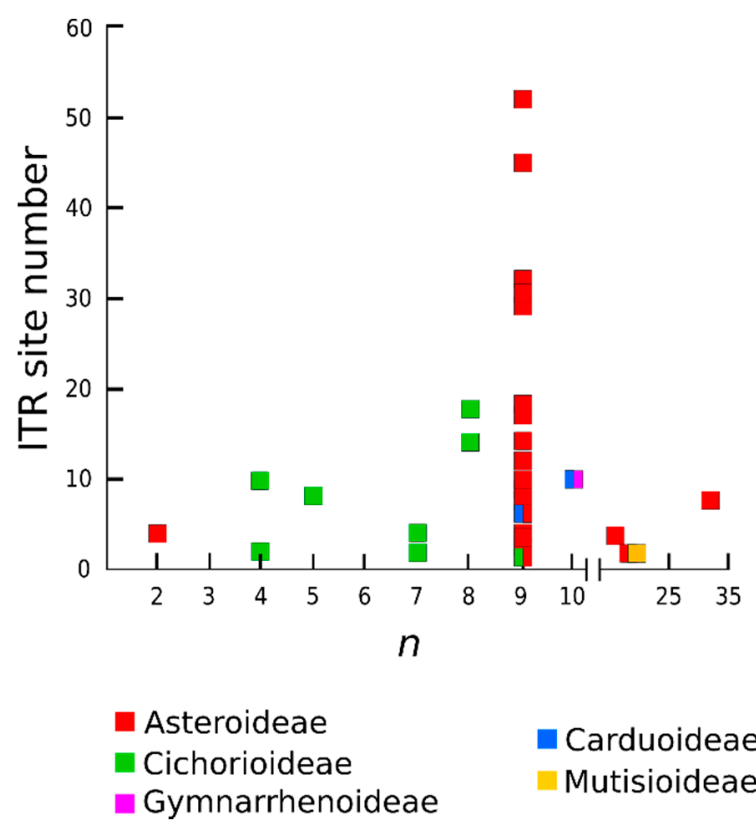

\section{- Carduoideae \\ Mutisioideae}

Figure 6. Relation between number of ITR sites and haploid chromosome number $(n)$ in Asteraceae.

ITR signals have been recorded from all regions of the chromosomes (centromeric, proximal and interstitial). However, the longitudinal distribution of ITR sites along the chromosome arms is uneven and their frequency was biased towards proximal and interstitialproximal regions (Figure 7A). Since a substantial number of records were contributed from the large sampling available from Anacyclus [49], the data were also reanalysed without the values from this genus (Figure 7B).

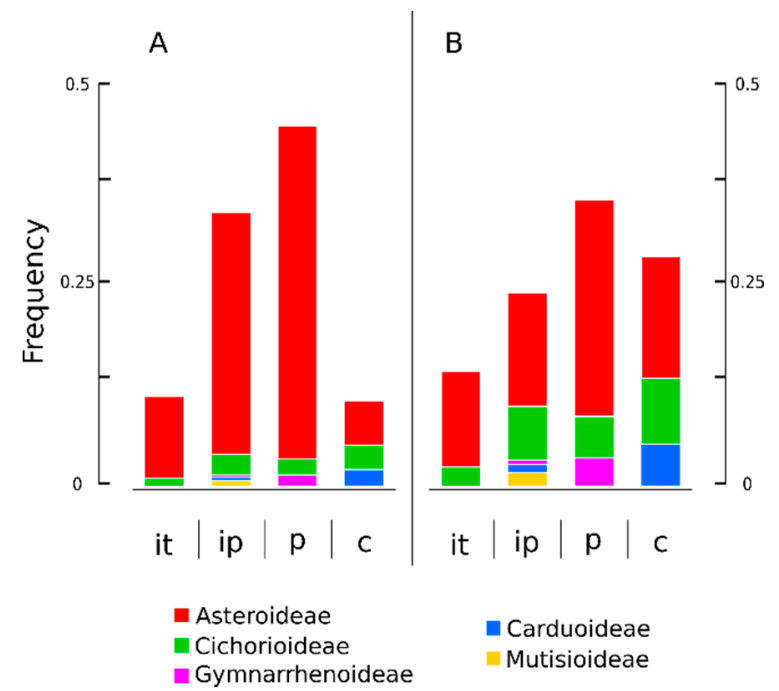

Figure 7. Longitudinal distribution of ITR sites along the chromosome arm in Asteraceae. The frequency in each chromosomal region is indicated. The chromosome arm was divided into four major domains of unequal size, i.e. centromeric (c), proximal (p), interstitial-proximal (ip), and interstitial-terminal (it). (A). Data from the whole dataset. (B) Data excluding Anacyclus.

In this case, there was an increase on the frequency of centromeric ITR sites and the concomitant decrease of the interstitial-proximal values. Centromeric signals were observed in species from Gonospermum, Tanacetum, Achillea, Galactites (Figure 2A), Carlina (Figure 2B), and Hyoseris (Figure 3C) (Table S1). However, non-centromeric ITR signals were also noted to co-occur for most of the samples. Only Tanacetum parthenium and Galactites tomentosa showed exclusively centromeric ITR signals (14 and 10, respectively). 


\section{Discussion}

Asteraceae, with nearly 180 analyzed species and subspecies, is the best sampled family of seed plants for the presence of ITR sites in chromosomes [53]. In this paper, we have significantly increased the phylogenetic and taxonomic coverage previously known for this family [8,32-50]. Together with the data we provided in a previous microevolutionary level study [49], we are confident that an assessment of the phylogenetic signal, taxonomic utility, and evolutionary significance of ITR features in Asteraceae can be done. However, ITR data are still lacking for seven subfamilies (Corymbieae, Pertyeae, Hecastocleideae, Wunderlichieae, Gochnatieae, Stifftieae and Famatinantheae) all representing small lineages containing a few species-and thus inferences made here have to be taken with some caution.

\subsection{The Long Evolutionary History of Asteraceae May Have Erased Phylogenetic Signals of ITR Sites}

The perception that ITRs represent a labile chromosomal landmark in Asteraceae is evidenced in this study. Variation related to presence, site number, chromosomal location and copy number regarding the presence of ITRs is scattered across evolutionary lineages (Figure 5). No association at high (subfamily, tribe, subtribe) or low taxonomic levels (genus, species) can be supported with our data. This is illustrated in Anthemideae, the most thoroughly sampled tribe to date ( 23 genera, 56 species and one subspecies) where ITR variation among congeneric species and between closely related genera is outstanding.

It should be emphasized that our survey was designed to prioritize the sampling of as many genera as possible at the expense of a low intrageneric coverage (ratio species/ genus $=1.22$ ). This precluded the assessment of ITR variation at low taxonomic ranks and shallow evolutionary levels (species and populations). Accordingly, it is likely that this biased sampling may have even underestimated the values of ITR variation at the generic and intraspecific levels. Our data obtained in Sonchus tenerrimus, where two intraspecific variants have yielded contrasting results concerning ITRs, point in this direction. Thus, it should not be discarded that analyzing more accessions from poorly sampled higher groups, where ITRs have not been detected, may reveal additional presences and even intraand interspecific polymorphisms, as has been previously reported in Anacyclus [49] and Tanacetum [50]. However, we think that additional data would not contradict the present evidence that ITRs are not appropriate markers in tracing phylogenetic relationships and helping delimit taxonomic boundaries in Asteraceae.

Whether the presence of ITR sites is an ancestral state in Asteraceae remains an open question deserving further studies. We have refrained from exploring evolutionary trends in ITR site change by maximum-likelihood or parsimony-based reconstruction due to the scarce data available for the early-diverging nodes. Available comparative data for related families indicate absence of ITRs (Table 1), including Calyceraceae, the sister family of Asteraceae. However, sampling is anecdotal and may be hardly used for outgroup purposes.

Another relevant question is whether ITR polymorphism is an odd genomic feature that is particularly represented in Asteraceae or it also affects other groups of angiosperms. In Fabaceae, the second most sampled family in flowering plants, the presence of ITRs have been assessed in 56 species included in 15 genera [7,8,44,54-74], where they were detected in seven not-closely related tribes (Cassiieae, Fabeae, Phaseoleae, Cicereae, Dalbergieae, Loteae and Trifolieae) [56,57,59,64-66,68,71-74]. Three genera belonging to different tribes showed both the presence and absence of ITRs (Phaseolus, Senna, Vicia) $[8,44,57,61,65,67,70,71,73,74]$ and intraspecific variation has been reported in Vicia faba $[8,44,61]$. This pattern for ITR variation, with no evident phylogenetic signal nor taxonomic utility, is consistent with the available data in Asteraceae.

It has been hypothesized that the origin of Asteraceae dates back to approximately $69.5 \mathrm{Ma}$ in the late Cretaceous and subfamilies diverged between 64.75 and $43.25 \mathrm{Ma}$ [75]. This long evolutionary history has been modulated by several episodes of genome du- 
plication (see below), adaptive radiation, and Cretaceous-Tertiary extinctions that have triggered diversification rate shifts [29,75-77].

An accurate interpretation of karyotype changes can be compromised if chromosomal changes have occurred in ancient and complex evolutionary scenarios. The accumulation of old genomic changes (e.g., past genome duplications or paleopolyploidy, neopolyploidization, chromosome rearrangements leading to subsequent dysploidy and diploidization processes) in short periods of time can hinder elucidating the imprints left by each one of them in the evolutionary history of extant karyotypes [78]. In Asteraceae, hypotheses on chromosomal base number evolution were reported by [29]. In this work, hypothesized base numbers for each of the 36 main clades were superimposed on the backbone phylogeny provided by [79] and two main patterns of karyotype change emerged, (1) polyploidy is common in Asteraceae and occurs in most major clades and (2) descending dysploid events (in contrast to the rarer increasing dysploidy) are widespread across major lineages. Later on, [80], using explicit models of chromosome evolution, corroborated previous inferences and suggested that karyological evolution has been a very dynamic process in Asteraceae mainly shaped by polyploidy and descending dysploidy scenarios.

It can also be inferred from our previous work [49] that the deduced fast ITR turnover occurring at the population level in Anacyclus is not clearly associated to speciation events and it is likely that this finding also applies to other unrelated lineages. Thus, available evidence suggest that ITR features in Asteraceae do not convey a strong evolutionary signal to be used in deciphering phylogenetic relationships and are also of little, if any, value in helping to delimit taxonomic boundaries. On the contrary, patterns of hypervariability, such as those reported for Anacyclus, makes ITR a suitable marker for tracing genomic changes at micro-evolutionary scales using cytogenetic approaches.

\subsection{Are Centromeric ITR Signals Remnants of Dysploidy in Asteraceae?}

In plants, the presence of ITR in centromeric and peri-centromeric locations has been considered to represent cytological landmarks related to dysploidy events e.g., [81-86]. There are two types of chromosomal rearrangements involved in dysploidy: end-to end chromosome fusions (symmetrical translocations) and fusion-fission cycle (Robertsonian rearrangements) between non-homologous chromosomes. Thus, on theoretical grounds ITR sites could be remnants of these karyological events. However, it has been pointed out that to acquire stability after chromosomal fusion events they should be accompanied by loss or inactivation of one of the centromeres and the resulting interstitial telomere sequences [78]. This view was modulated by [83], who indicated that the interstitial telomere sequences may be preserved during the chromosomal rearrangements because the telomere region of one chromosome is the breakpoint and therefore partially participates in the reciprocal translocation between the two acrocentric or telocentric chromosomes involved in the rearrangement.

If ITR sites in Asteraceae were in fact cytogenetic signatures of disploidy, one question to be addressed is why ITR number contrasts between related species showing the same derived chromosome numbers. This is illustrated in the case of Brachyschome dichromosomatica and Xanthisma gracile, two species showing the highly reduced $2 n=4$ chromosome number (the lowest chromosome number so far reported in seed plants). From the available evidence, it seems highly likely that the $2 n=4$ karyotype was originated through many rounds of descendent disploidy events. Surprisingly, no ITRs have been documented in $B$. dichromosomatica [32], whereas in X. gracile two contrasting reports recording zero and four non-centromeric ITR sites are known $[7,8,38]$.

Altogether, our data suggest that in Asteraceae the dynamics of ITR formation is too fast or labile to trace the complex karyological evolution that has been hypothesized to occur since the early diversification events in the family [75,80]. Further, part of such lability could be due to other types of karyological changes that erased previous ITR signs inconsistently across lineages. 


\section{Materials and Methods}

\subsection{Plant Materials}

Seeds were collected in the field or were supplied by botanical gardens, plant breeding stations, research centres and commercial sources. The name and origin of the plant accessions used are provided in Table S2. Representative herbarium and seeds vouchers are deposited at the herbarium of the Botanical Garden of Valencia University (VAL) and the Germplasm banks of the Real Jardín Botánico de Madrid and the Botanical Garden of Valencia University. For comparative purposes, two species belonging to the related Calyceraceae and Goodeniaceae families (Asterales) were also studied.

\subsection{FISH Analysis}

Protocols for seed germination and the obtention of mitotic chromosomes follow the experimental procedures described in [87]. The telomeric sequence TTTAGGG was localised using the pAtT4 clone isolated from Arabidopsis thaliana [88]. The probe was labelled with biotin-16-dUTP through a nick translation procedure according to the manufacturer's protocols (Roche, Germany). Probe detection was conducted using the method of [89] with the modifications described by [90].

\subsection{Karyotype Analysis}

For each accession, well spread metaphase plates were selected for assessing the chromosome number and the presence of ITRs. Individuals showing ITRs were further analyzed and the number of sites and their location along the chromosome were recorded. The chromosome arm was divided into four domains of equal size according to [91], i.e., centromeric (c), proximal (p), interstitial-proximal (ip), and interstitial-terminal (it) and the ITR sites detected were mapped on these chromosomal regions. Since most karyotypes of Asteraceae show metacentric chromosomes a reliable distinction between both arms was usually not feasible. Accordingly, the locations of ITR sites on both chromosome arms were pooled. Chromosome measurements were made on digital images using the computer application MicroMeasure version 3.2 [92].

The overview of the phylogenetic relationships among tribes is based on [27]. The tree was redrawn using the iTOL application [93] and Inkscape software.

Supplementary Materials: The following are available online at https:/ /www.mdpi.com/article/10 .3390 / plants10122794/s1, Table S1: Distribution of ITR sites in Asteraceae and related families of Asterales, Table S2: List of studied accessions and sources of analyzed material by FISH.

Author Contributions: Conceptualization, M.R. and J.A.R.; methodology, A.J.M. and M.R.; formal analysis, A.J.M., M.R., I.Á., G.N.F. and J.A.R.; data curation, A.J.M. and M.R.; writing-original draft preparation, M.R. and J.A.R.; writing—review and editing, A.J.M., M.R., I.Á., G.N.F. and J.A.R.; supervision, J.A.R.; funding acquisition, G.N.F. All authors have read and agreed to the published version of the manuscript.

Funding: This research was partly funded by grants from the Spanish Ministry of Economy and Competitiveness through the projects CGL2013-49097-C2-1-P and CGL2017-88500-P.

Institutional Review Board Statement: Not applicable.

Informed Consent Statement: Not applicable.

Data Availability Statement: Not applicable.

Acknowledgments: We thank J. Fabado, P.P. Ferrer-Gallego, P. Fraga, A. Galán de Mera, M. Piera, J. Riera and the staff and curators of the seed banks listed in Table S1 for kindly providing the accessions used in this study. The facilities given by the directors and technical units of the Botanical Gardens of Valencia and Madrid are warmly acknowledged.

Conflicts of Interest: The authors declare no conflict of interest. 


\section{References}

1. Blackburn, E.H. Structure and function of telomeres. Nature 1991, 350, 569-573. [CrossRef] [PubMed]

2. Nelson, A.D.; Beilstein, M.A.; Shippen, D.E. Plant telomeres and telomerase. In Molecular Biology; Howell, S.H., Ed.; Springer: New York, NY, USA, 2014; pp. 25-49.

3. O'Sullivan, R.J.; Karlseder, J. Telomeres: Protecting chromosomes against genome instability. Nat. Rev. Mol. Cell Biol. 2010, 11, 171-181. [CrossRef]

4. Procházková Schrumpfová, P.; Fojtová, M.; Fajkus, J. Telomeres in plants and humans: Not so different, not so similar. Cells 2019, 8, 58. [CrossRef] [PubMed]

5. Fajkus, J.; Sýkorová, E.; Leitch, A.R. Telomeres in evolution and evolution of telomeres. Chromosome Res. 2005, 13, 469-479. [CrossRef]

6. Fulnečková, J.; Ševčíková, T.; Fajkus, J.; Lukešova, A.; Lukeš, M.; Vlček, Č.; Lang, F.B.; Kim, E.; Eliáš, M.; Sýkorova, E. A broad phylogenetic survey unveils the diversity and evolution of telomeres in eukaryotes. Genome Biol. Evol. 2013, 5, 468-483. [CrossRef]

7. Cox, A.V.; Bennett, S.T.; Parokonny, A.S.; Kenton, A.; Callimassia, M.A.; Bennett, M.D. Comparison of plant telomere locations using a PCR-generated synthetic probe. Ann. Bot. 1993, 72, 239-247. [CrossRef]

8. Fuchs, J.; Brandes, A.; Schubert, I. Telomere sequence localization and karyotype evolution in higher plants. Plant Syst. Evol. 1995, 196, 227-241. [CrossRef]

9. Weiss, H.; Scherthan, H. Aloe spp.-Plants with vertebrate-like telomeric sequences. Chromosome Res. 2002, 10, 155-164. [CrossRef] [PubMed]

10. Puizina, J.; Weiss-Schneeweiss, H.; Pedrosa-Harand, A.; Kamenjarin, J.; Trinajstić, I.; Riha, K.; Schweizer, D. Karyotype analysis in Hyacinthella dalmatica (Hyacinthaceae) reveals vertebrate-type telomere repeats at the chromosome ends. Genome 2003, 46, 1070-1076. [CrossRef]

11. Sýkorová, E.; Lim, K.Y.; Fajkus, J.; Leitch, A.R. The signature of the Cestrum genome suggests an evolutionary response to the loss of (TTTAGGG) $\mathrm{n}$ telomeres. Chromosoma 2003, 112, 164-172. [CrossRef] [PubMed]

12. Fajkus, P.; Peška, V.; Sitová, Z.; Fulnečková, J.; Dvořáčková, M.; Gogela, R.; Sýkorová, E.; Fajkus, J. Allium telomeres unmasked: The unusual telomeric sequence (CTCGGTTATGGG) $n$ is synthesized by telomerase. Plant J. 2016, 85, 337-347. [CrossRef]

13. Sýkorová, E.; Lim, K.Y.; Chase, M.W.; Knapp, S.; Leitch, I.J.; Leitch, A.R.; Fajkus, J. The absence of Arabidopsis-type telomeres in Cestrum and closely related genera Vestia and Sessea (Solanaceae): First evidence from eudicots. Plant J. 2003, 34, $283-291$. [CrossRef] [PubMed]

14. Sýkorová, E.; Lim, K.Y.; Kunická, Z.; Chase, M.W.; Bennett, M.D.; Fajkus, J.; Leitch, A.R. Telomere variability in the monocotyledonous plant order Asparagales. Proc. R. Soc. Lond. Ser. B Biol. Sci. 2003, 270, 1893-1904. [CrossRef] [PubMed]

15. Peška, V.; Sýkorová, E.; Fajkus, J. Two faces of Solanaceae telomeres: A comparison between Nicotiana and Cestrum telomeres and telomere-binding proteins. Cytogenet. Genome Res. 2008, 122, 380-387. [CrossRef] [PubMed]

16. Peška, V.; Fajkus, P.; Fojtová, M.; Dvořáčková, M.; Hapala, J.; Dvořáček, V.; Polanská, P.; Leitch, A.R.; Sýkorová, E.; Fajkus, J. Characterisation of an unusual telomere motif (TTTTTTAGGG) $\mathrm{n}$ in the plant Cestrum elegans (Solanaceae), a species with a large genome. Plant J. 2015, 82, 644-654. [CrossRef]

17. Tran, T.D.; Cao, H.X.; Jovtchev, G.; Neumann, P.; Novák, P.; Fojtová, M.; Vu, G.T.H.; Macas, J.; Fajkus, J.; Schubert, I.; et al. Centromere and telomere sequence alterations reflect the rapid genome evolution within the carnivorous plant genus Genlisea. Plant J. 2015, 84, 1087-1099. [CrossRef] [PubMed]

18. Peska, V.; García, S. Origin, diversity, and evolution of telomere sequences in plants. Front. Plant Sci. 2020, 11, 117. [CrossRef] [PubMed]

19. Lin, K.W.; Yan, J. Endings in the middle: Current knowledge of interstitial telomeric sequences. Mutat. Res. Rev. Mutat. Res. 2008, 658, 95-110. [CrossRef] [PubMed]

20. Meyne, J.; Baker, R.J.; Hobart, H.H.; Hsu, T.C.; Ryder, O.A.; Ward, O.G.; Wiley, J.E.; Wurster-Hill, D.H.; Yates, T.L.; Moyzis, R.K. Distribution of non-telomeric sites of the (TTAGGG) $)_{n}$ telomeric sequence in vertebrate chromosomes. Chromosoma 1990, 99, 3-10. [CrossRef] [PubMed]

21. Aksenova, A.Y.; Greenwell, P.W.; Dominska, M.; Shishkin, A.A.; Kim, J.C.; Petes, T.D.; Mirkin, S.M. Genome rearrangements caused by interstitial telomeric sequences in yeast. Proc. Natl. Acad. Sci. USA 2013, 110, 19866-19871. [CrossRef]

22. Ocalewicz, K. Telomeres in fishes. Cytogenet. Genome Res. 2013, 141, 114-125. [CrossRef] [PubMed]

23. Bolzán, A.D. Interstitial telomeric sequences in vertebrate chromosomes: Origin, function, instability and evolution. Mutat. Res. Rev. Mutat. Res. 2017, 773, 51-65. [CrossRef] [PubMed]

24. Aksenova, A.Y.; Mirkin, S.M. At the beginning of the end and in the middle of the beginning: Structure and maintenance of telomeric DNA repeats and interstitial telomeric sequences. Genes 2019, 10, 118. [CrossRef]

25. Ruiz-Herrera, A.; Nergadze, S.G.; Santagostino, M.; Giulotto, E. Telomeric repeats far from the ends: Mechanisms of origin and role in evolution. Cytogenet. Genome Res. 2008, 122, 219-228. [CrossRef] [PubMed]

26. Vitales, D.; D'Ambrosio, U.; Gálvez, F.; Kovařík, A.; García, S. Third release of the plant rDNA database with updated content and information on telomere composition and sequenced plant genomes. Plant Syst. Evol. 2017, 303, 1115-1121. [CrossRef]

27. Mandel, J.R.; Dikow, R.B.; Siniscalchi, C.M.; Thapa, R.; Watson, L.E.; Funk, V.A. A fully resolved backbone phylogeny reveals numerous dispersals and explosive diversifications throughout the history of Asteraceae. Proc. Natl. Acad. Sci. USA 2019, 116, 14083-14088. [CrossRef] [PubMed] 
28. Raven, P.H.; Solbrig, O.T.; Kyhos, D.W.; Snow, R. Chromosome numbers in Compositae. I. Astereae. Am. J. Bot. 1960, 47, 124-132. [CrossRef]

29. Semple, J.C.; Watanabe, K. A review of chromosome numbers in Asteraceae with hypotheses on chromosomal base number evolution. In Systematics, Evolution, and Biogeography of Compositae, 1st ed.; Funk, V.A., Susanna, A., Stuessy, T.F., Bayer, R.J., Eds.; International Association for Plant Taxonomy: Vienna, Austria, 2009; pp. 61-72.

30. Bala, S.; Gupta, R.C. Male meiosis and chromosome number in Asteraceae family from district Kangra of HP (Western Himalayas). Int. J. Bot. Res. 2013, 3, 43-58.

31. Huang, C.H.; Zhang, C.; Liu, M.; Hu, Y.; Gao, T.; Qi, J.; Ma, H. Multiple polyploidization events across Asteraceae with two nested events in the early history revealed by nuclear phylogenomics. Mol. Biol. Evol. 2016, 33, 2820-2835. [CrossRef] [PubMed]

32. Houben, A.; Thompson, N.; Ahne, R.; Leach, C.R.; Verlin, D.; Timmis, J.N. A monophyletic origin of the B chromosomes of Brachycome dichromosomatica (Asteraceae). Plant Syst. Evol. 1999, 219, 127-135. [CrossRef]

33. Adams, S.P.; Hartman, T.P.V.; Lim, K.Y.; Chase, M.W.; Bennett, M.D.; Leitch, I.J.; Leitch, A.R. Loss and recovery of Arabidopsis-type telomere repeat sequences $5^{\prime}-(\text { TTTAGGG })_{n}-3^{\prime}$ in the evolution of a major radiation of flowering plants. Proc. R. Soc. Lond. Ser. $B$ Biol. Sci. 2001, 268, 1541-1546. [CrossRef]

34. Borgen, L.; Leitch, I.; Santos-Guerra, A. Genome organization in diploid hybrid species of Argyranthemum (Asteraceae) in the Canary Islands. Bot. J. Linn. Soc. 2003, 141, 491-501. [CrossRef]

35. Pires, J.C.; Lim, K.Y.; Kovarík, A.; Matyásek, R.; Boyd, A.; Leitch, A.R.; Bennett, N.D.; Soltis, P.S.; Soltis, D.E. Molecular cytogenetic analysis of recently evolved Tragopogon (Asteraceae) allopolyploids reveal a karyotype that is additive of the diploid progenitors. Am. J. Bot. 2004, 91, 1022-1035. [CrossRef] [PubMed]

36. Abd El-Twab, M.H.; Kondo, K. FISH physical mapping of 5S, 45S and Arabidopsis-type telomere sequence repeats in Chrysanthemum zawadskii showing intra-chromosomal variation and complexity in nature. Chromosome Bot. 2006, 1, 1-5. [CrossRef]

37. Abd El-Twab, M.H.; Kondo, K. FISH physical mapping of 5S rDNA and telomere sequence repeats identified a peculiar chromosome mapping and mutation in Leucanthemella linearis and Nipponanthemum nipponicum in Chrysanthemum sensu lato. Chromosome Bot. 2007, 2, 11-17. [CrossRef]

38. Hanmoto, H.; Kataoka, R.; Ohmido, N.; Yonezawa, Y. Interstitial telomere-like repeats in the Haplopappus gracilis (Asteraceae) genome revealed by fluorescence in situ hybridization. Cytologia 2007, 72, 483-488. [CrossRef]

39. Matoba, H.; Mizutani, T.; Nagano, K.; Hoshi, Y.; Uchiyama, H. Chromosomal study of lettuce and its allied species (Lactuca spp.; Asteraceae) by means of karyotype analysis and fluorescence in situ hybridization. Hereditas 2007, 144, 235-243. [CrossRef] [PubMed]

40. Abd El-Twab, M.H.; Kondo, K. Physical mapping of 5S, 45S, Arabidopsis-type telomere sequence repeats and AT-rich regions in Achillea millefolium showing intrachromosomal variation by FISH and DAPI. Chromosome Bot. 2009, 4, 37-45. [CrossRef]

41. Dydak, M.; Kolano, B.; Nowak, T.; Siwinska, D.; Maluszynska, J. Cytogenetic studies of three European species of Centaurea L. (Asteraceae). Hereditas 2009, 146, 152-161. [CrossRef]

42. García, S.; Garnatje, T.; Pellicer, J.; McArthur, E.D.; Siljak-Yakovlev, S.; Vallés, J. Ribosomal DNA, heterochromatin, and correlation with genome size in diploid and polyploid North American endemic sagebrushes (Artemisia, Asteraceae). Genome 2009, 52, 1012-1024. [CrossRef]

43. Matoba, H.; Uchiyama, H. Physical mapping of 5S rDNA, 18S rDNA and telomere sequences in three species of the genus Artemisia (Asteraceae) with distinct basic chromosome numbers. Cytologia 2009, 74, 115-123. [CrossRef]

44. Shibata, F.; Hizume, M. Survey of Arabidopsis- and human-type telomere repeats in plants using fluorescence in situ hybridisation. Cytologia 2011, 76, 353-360. [CrossRef]

45. Li, J.; He, S.; Zhang, L.; Hu, Y.; Yang, F.; Ma, L.; Huang, J.; Li, L. Telomere and 45S rDNA sequences are structurally linked on the chromosomes in Chrysanthemum segetum L. Protoplasma 2012, 249, 207-215. [CrossRef] [PubMed]

46. Cuyacot, A.R.; Won, S.Y.; Park, S.K.; Sohn, S.H.; Lee, J.; Kim, J.S.; Kim, H.H.; Lim, K.M.; Hwang, Y.J. The chromosomal distribution of repetitive DNA sequences in Chrysanthemum boreale revealed a characterization in its genome. Sci. Hortic. 2016, 198, 438-444. [CrossRef]

47. Cuyacot, A.R.; Lim, K.B.; Kim, H.H.; Hwang, Y.J. Chromosomal characterization based on repetitive DNA distribution in a tetraploid cytotype of Chrysanthemum zawadskii. Hortic. Environ. Biotechnol. 2017, 58, 488-494. [CrossRef]

48. Mancia, F.H.; Ju, Y.H.; Lim, K.B.; Kim, J.S.; Nam, S.Y.; Hwang, Y.J. Cytogenetic mapping of Carthamus tinctorius L. with tandemly repeated DNA sequences by fluorescence in situ hybridization. Korean J. Plant Res. 2017, 30, 654-661.

49. Rosato, M.; Álvarez, I.; Nieto Feliner, G.; Rosselló, J.A. Inter- and intraspecific hypervariability in interstitial telomeric-like repeats (TTTAGGG) $\mathrm{n}$ in Anacyclus (Asteraceae). Ann. Bot. 2018, 122, 387-395. [CrossRef] [PubMed]

50. Mlinarec, J.; Skuhala, A.; Jurković, A.; Malenica, N.; McCann, J.; Weiss-Schneeweiss, H.; Bohanec, B.; Besendorfer, V. The repetitive DNA composition in the natural pesticide producer Tanacetum cinerariifolium: Interindividual variation of subtelomeric tandem repeats. Front. Plant Sci. 2019, 10, 613. [CrossRef]

51. Schwarzacher, T.; Heslop-Harrison, J.S. In situ hybridization to plant telomeres using synthetic oligomers. Genome 1991, 34, 317-323. [CrossRef]

52. Leitch, A.R.; Schwarzacher, T.; Jackson, D.; Leitch, I.J. In Situ Hybridization: A Practical Guide; BIOS Scientific Publishers Ltd.: Oxford, UK, 1994. 
53. Maravilla, A.J.; Rosato, M.; Rosselló, J.A. Interstitial telomeric-like repeats (ITR) in seed plants as assessed by molecular cytogenetic techniques: A review. Plants 2021, 10, 2541. [CrossRef]

54. Rawlins, D.J.; Highett, M.I.; Shaw, P.J. Localization of telomeres in plant interphase nuclei by in situ hybridization and 3D confocal microscopy. Chromosoma 1991, 100, 424-431. [CrossRef]

55. Thomas, H.M.; Williams, K.; Harper, J.A. Labelling telomeres of cereals, grasses and clover by primed in situ DNA labelling Chromosome Res. 1996, 4, 182-184. [CrossRef] [PubMed]

56. Gortner, G.; Nenno, M.; Weising, K.; Zink, D.; Nagl, W.; Kahl, G. Chromosomal localization and distribution of simple sequence repeats and the Arabidopsis-type telomere sequence in the genome of Cicer arietinum L. Chromosome Res. 1998, 6, 97-104. [CrossRef] [PubMed]

57. Nenno, M.; Zink, D.; Nagl, W. The Arabidopsis telomere sequence is highly abundant in the genome of Phaseolus acutifolius and preferentially located in the centromeres. Annu. Rep.-Bean Improv. Coop. 1998, 41, 103-104.

58. Galasso, I.; Schmidt, T.; Pignone, D. Identification of Lens culinaris ssp. culinaris chromosomes by physical mapping of repetitive DNA sequences. Chromosome Res. 2001, 9, 199-209. [PubMed]

59. Pedrosa, A.; Sandal, N.; Stougaard, J.; Schweizer, D.; Bachmair, A. Chromosomal map of the model legume Lotus japonicus. Genetics 2002, 161, 1661-1672. [CrossRef]

60. Hajdera, I.; Siwinska, D.; Hasterok, R.; Maluszynska, J. Molecular cytogenetic analysis of genome structure in Lupinus angustifolius and Lupinus cosentinii. Theor. Appl. Genet. 2003, 107, 988-996. [CrossRef] [PubMed]

61. Navrátilová, A.; Neumann, P.; Macas, J. Karyotype analysis of four Vicia species using in situ hybridization with repetitive sequences. Ann. Bot. 2003, 91, 921-926. [CrossRef] [PubMed]

62. Macas, J.; Neumann, P.; Navrátilová, A. Repetitive DNA in the pea (Pisum sativum L.) genome: Comprehensive characterization using 454 sequencing and comparison to soybean and Medicago truncatula. BMC Genom. 2007, 8, 427. [CrossRef] [PubMed]

63. Kaczmarek, A.; Naganowska, B.; Wolko, B. Karyotyping of the narrow-leafed lupin (Lupinus angustifolius L.) by using FISH, PRINS and computer measurements of chromosomes. J. Appl. Genet. 2009, 50, 77-82. [CrossRef] [PubMed]

64. Zatloukalová, P.; Hřibová, E.; Kubaláková, M.; Suchánková, P.; Šimková, H.; Adoración, C.; Kahl, G.; Millán, T.; Doležel, J. Integration of genetic and physical maps of the chickpea (Cicer arietinum L.) genome using flow-sorted chromosomes. Chromosome Res. 2011, 19, 729-739. [CrossRef] [PubMed]

65. Fonsêca, A.; Pedrosa-Harand, A. Karyotype stability in the genus Phaseolus evidenced by the comparative mapping of the wild species Phaseolus microcarpus. Genome 2013, 56, 335-343. [CrossRef]

66. Du, P.; Li, L.N.; Zhang, Z.X.; Liu, H.; Qin, L.; Huang, B.Y.; Dong, W.; Tang, F.; Qi, Z.; Zhang, X.Y. Chromosome painting of telomeric repeats reveals new evidence for genome evolution in peanut. J. Integr. Agric. 2016, 15, 2488-2496. [CrossRef]

67. Fonsêca, A.; Ferraz, M.E.; Pedrosa-Harand, A. Speeding up chromosome evolution in Phaseolus: Multiple rearrangements associated with a one-step descending dysploidy. Chromosoma 2016, 125, 413-421. [CrossRef] [PubMed]

68. Zhang, L.; Yang, X.; Tia, L.; Chen, L.; Yu, W. Identification of peanut (Arachis hypogaea) chromosomes using a fluorescence in situ hybridization system reveals multiple hybridization events during tetraploid peanut formation. New Phytol. 2016, 211, 1424-1439. [CrossRef] [PubMed]

69. Waminal, N.E.; Pellerin, R.J.; Kim, N.S.; Jayakodi, M.; Park, J.Y.; Yang, T.J.; Kim, H.H. Rapid and efficient FISH using pre-labeled oligomer probes. Sci. Rep. 2018, 8, 1-10. [CrossRef] [PubMed]

70. Youn, S.M.; Kim, H.H. Chromosome karyotyping of Senna covesii and S. floribunda based on triple-color FISH mapping of rDNAs and telomeric repeats. Plant Breed. Biotechnol. 2018, 6, 51-56. [CrossRef]

71. Pellerin, R.J.; Waminal, N.E.; Kim, H.H. FISH mapping of rDNA and telomeric repeats in 10 Senna species. Hortic. Environ. Biotechnol. 2019, 60, 253-260. [CrossRef]

72. Falistocco, E. Insight into the chromosome structure of the cultivated tetraploid alfalfa (Medicago sativa subsp. sativa L.) by a combined use of GISH and FISH techniques. Plants 2020, 9, 542. [CrossRef]

73. Nguyen, T.H.; Waminal, N.E.; Lee, D.S.; Pellerin, R.J.; Ta, T.D.; Campomayor, N.B.; Kang, B.Y.; Kim, H.H. Comparative triple-color FISH mapping in eleven Senna species using rDNA and telomeric repeat probes. Hortic. Environ. Biotechnol. 2021, 62, 927-935. [CrossRef]

74. Waminal, N.E.; Pellerin, R.J.; Kang, S.H.; Kim, H.H. Chromosomal mapping of tandem repeats revealed massive chromosomal rearrangements and insights into Senna tora dysploidy. Front. Plant Sci. 2021, 12, 154. [CrossRef]

75. Panero, J.L.; Crozier, B.S. Macroevolutionary dynamics in the early diversification of Asteraceae. Mol. Phylogenet. Evol. 2016, 99, 116-132. [CrossRef]

76. Barker, M.S.; Kane, N.C.; Matvienko, M.; Kozik, A.; Michelmore, R.W.; Knapp, S.J.; Rieseberg, L.H. Multiple paleopolyploidizations during the evolution of the Compositae reveal parallel patterns of duplicate gene retention after millions of years. Mol. Biol. Evol. 2008, 25, 2445-2455. [CrossRef] [PubMed]

77. Barker, M.S.; Li, Z.; Kidder, T.I.; Reardon, C.R.; Lai, Z.; Oliveira, L.O.; Scascitelli, M.; Rieseberg, L.H. Most Compositae (Asteraceae) are descendants of a paleohexaploid and all share a paleotetraploid ancestor with the Calyceraceae. Am. J. Bot. 2016, 103, 1203-1211. [CrossRef] [PubMed]

78. Schubert, I.; Lysak, M.A. Interpretation of karyotype evolution should consider chromosome structural constraints. Trends Genet. 2011, 27, 207-216. [CrossRef] [PubMed] 
79. Funk, V.A.; Bayer, R.J.; Keeley, S.; Chan, R.; Watson, L.; Gemeinholzer, B.; Schilling, E.; Panero, J.L.; Baldwin, B.G.; García-Jacas, N.; et al. Everywhere but Antarctica: Using a supertree to understand the diversity and distribution of the Compositae. Biol. Skr. 2005, 55, 343-374

80. Mota, L.; Torices, R.; Loureiro, J. The evolution of haploid chromosome numbers in the sunflower family. Genome Biol. Evol. 2016, 8, 3516-3528. [CrossRef] [PubMed]

81. Raskina, O.; Barber, J.C.; Nevo, E.; Belyayev, A. Repetitive DNA and chromosomal rearrangements: Speciation-related events in plant genomes. Cytogenet. Genome Res. 2008, 120, 351-357. [CrossRef] [PubMed]

82. Kim, E.S.; Bolshev, N.L.; Samatadze, T.E.; Nosov, N.N.; Nosova, I.V.; Zelenin, A.V.; Punina, E.O.; Muravenko, O.V.; Rodionov, A.V. The unique genome of two-chromosome grasses Zingeria and Colpodium, its origin, and evolution. Russ. J. Genet. 2009, 45, 1329-1337. [CrossRef]

83. Sousa, A.; Cusimano, N.; Renner, S.S. Combining FISH and model-based predictions to understand chromosome evolution in Typhonium (Araceae). Ann. Bot. 2014, 113, 669-680. [CrossRef]

84. Amosova, A.V.; Bolsheva, N.L.; Samatadze, T.E.; Twardovska, M.O.; Zoshchuk, S.A.; Andreev, I.O.; Badaeva, E.D.; Kunakh, V.A.; Muravenko, O.V. Molecular cytogenetic analysis of Deschampsia antarctica Desv. (Poaceae), Maritime Antarctic. PLoS ONE 2015, 10, e0138878. [CrossRef] [PubMed]

85. Rockinger, A.; Sousa, A.; Carvalho, F.A.; Renner, S.S. Chromosome number reduction in the sister clade of Carica papaya with concomitant genome size doubling. Am. J. Bot. 2016, 103, 1082-1088. [CrossRef] [PubMed]

86. Souza, G.; Vanzela, A.L.; Crosa, O.; Guerra, M. Interstitial telomeric sites and Robertsonian translocations in species of Ipheion and Nothoscordum (Amaryllidaceae). Genetica 2016, 144, 157-166. [CrossRef]

87. Rosato, M.; Castro, M.; Rosselló, J.A. Relationships of the woody Medicago species (section Dendrotelis) assessed by molecular cytogenetic analyses. Ann. Bot. 2008, 102, 15-22. [CrossRef] [PubMed]

88. Richards, E.J.; Ausubel, F.M. Isolation of a higher eukaryotic telomere from Arabidopsis thaliana. Cell 1998, 53, 127-136. [CrossRef]

89. Zhong, X.; Fransz, P.F.; Wennekes-van Eden, J.; Zabel, P.; Van Kammen, A.; De Jong, H.J. High-resolution mapping on pachytene chromosomes extended DNA fibres by fluorescence in-situ hybridisation. Plant Mol. Biol. Rep. 1996, 14, 232-242. [CrossRef]

90. Galián, J.A.; Rosato, M.; Rosselló, J.A. Incomplete sequence homogenization in 45S rDNA multigene families: Intermixed IGS heterogeneity within the single NOR locus of the polyploid species Medicago arborea (Fabaceae). Ann. Bot. 2014, 114, $243-251$. [CrossRef]

91. Roa, F.; Guerra, M. Distribution of $45 \mathrm{~S}$ rDNA sites in chromosomes of plants: Structural and evolutionary implications. BMC Evol. Biol. 2012, 12, 225. [CrossRef] [PubMed]

92. Reeves, A. MicroMeasure: A new computer program for the collection and analysis of cytogenetic data. Genome 2001, 44, 439-443. [CrossRef]

93. Letunic, I.; Bork, P. Interactive Tree of Life (iTOL) v5: An online tool for phylogenetic tree display and annotation. Nucleic Acids Res. 2021, 49, W293-W296. [CrossRef] [PubMed] 